\title{
Establishment of Barbwire Russian Thistle in Desert Environments
}

\author{
RAYMOND A. EVANS AND JAMES A. YOUNG
}

\begin{abstract}
Barbwire Russian thistle dominated a degraded plant community in the Carson Desert of northwestern Nevada and completely excluded Russian thistle in the course of the study. In seeding trials barbwire Russian thistle became established at low levels under arid conditions of the desert while Russian thistle failed to become established. Under semiarid conditions, seedling establishment of Russian thistle was five time greater than that of barbwire Russian thistle. Adaptations of barbwire Russian thistle that apparently favor seedling establishment under arid desert environments include earlier maturation and seed dispersal, seed dispersal beneath the parent plant, and less specific afterripening requirements than Russian thistle. These adaptations would permit germination and seedling establishment in the relatively wet periods of late winter and early spring in this arid ecosystem.
\end{abstract}

Barbwire Russian thistle (Salsola paulsenii) has been recognized as an important range plant only in the last decade. Failure to identify barbwire Russian thistle as a separate taxon from Russian thistle (S. iberica) led to confusion even though workers from diverse disciplines recognized that more than one ecological and physiological type of Russian thistle existed in the Great Basin and in California. Beatley (1973) alleviated this confusion by recognizing and describing the characteristics of both species. There are still questions concerning the amount of variability that should be included in the taxon S. paulsenii . However, Arnold (1972) presents evidence that plants with both lax and spinose perianth tips that otherwise fit the characteristics of S. paulsenii should be included, barring further evidence to the contrary, in that taxon.

Other than the taxonomic considerations, little is known about barbwire Russian thistle. Beatley (1971) established that this species is a widespread dominant of low-elevation disturbed sites in the southern Great Basin. In that area barbwire Russian thistle shows an affinity for soil derived from limestone.

Observation in the Carson Desert of western Nevada in

Authors are range scientists, U.S. Department of Agriculture, Science and Education Administration, Agricultural Research, Renewable Resource Center, University of Nevada, 920 Valley Rd., Reno 89512.

This study is a contribution from U.S. Dep. Agr., Science and Education Administration, Agricultural Research, and the Agricultural Experiment Station, Univ. of Nevada. Journal Series No. 425.

Manuscript received November 10, 1978. the early 1970's revealed extensive stands of barbwire Russian thistle that appeared to be replacing Russian thistle. Such replacement has not occurred on most agricultural soils in the area.

In previous studies we determined some of the basic germination characteristics of barbwire Russian thistle seeds (Young and Evans 1979). Seed germination and seedbed ecology have been studied for Russian thistle (Young and Evans 1972; Evans and Young 1972a).

The purpose of this study was to determine various aspects of the production of seeds by barbwire Russian thistle in the field and to study the seedbed behavior of Russian thistle and barbwire Russian thistle on desert range and agricultural soils.

\section{Methods}

Field studies were conducted in 1973 through 1976 at Dodge Flat in the Carson Desert near Wadsworth, Nevada. The study site is located in the dry bottom of pluvial Lake Lahontan in a landscape that Morrison (1964) described as the most stark and foreboding in the western United States. Dodge Flat was used as a livestock-concentration site for the wool and livestock shipping point at Wadsworth. More recently the plant communities have been excessively utilized by yearlong cattle grazing on the Pyramid Lake Indian reservation. During the 1950 's Dodge Flat was the site of extensive programs to control halogeton (Halogeton glomeratus). The potential plant communities, soils, and climate of the Carson Desert are described by Billings (1945).

Annually, in November, we sampled the plant communities when the current year's seeds were ripe, but had not yet dehisced. Sampling units were 100 randomly located $1-\mathrm{m}^{2}$ plots. If any Salsola plants were rooted in a plot, the density and cover were recorded and the plants were pulled and bagged for determination of seed production. The bagged plants were weighed to determine herbage yield, their seed were separated by hand, counted and weighed to determine seed weight. In addition to the density and cover determinations, the species composition in the communities was determined by frequency sampling with the procedures developed by Evans and Love (1957).

We began a competition study on an agriculture sandy loam soil at Reno, Nev., in December 1974. Four replications per treatment in a randomized block design were used. Treatments were applied to $1-\mathrm{m}^{2}$ plots with a $1-\mathrm{m}$ border around each plot. Seeding rate was 5,000 seeds $/ \mathrm{m}^{2}$. Seeding treatments consisted of Russian thistle 
and barbwire Russian thistle separately and both species mixed together. Seeds of all species were raked into the surface $1 \mathrm{~cm}$ of soil. The seeds of barbwire Russian thistle had been produced in 1974; the seeds of Russian thistle had been produced in 1973 and were 1 year old at the time of planting and had $90 \%$ germination at $20^{\circ} \mathrm{C}$. The experiment was repeated in March 1975, but seeds were sprinkled on the soil surface without soil coverage. The experiment was repeated in December 1975 at Reno and at Dodge Flat; seeds of both species were from the current year and were sprinkled on the soil surface. The plots were sampled as soon as germination was apparent and periodically throughout the growing season. Sampling consisted of four sets of $0.1-\mathrm{m}^{2}$ density and cover determinations from each plot and four sets of frequency samples with a 10-point frame (Levy and Madden 1933).

\section{Results and Discussion}

\section{Characteristics of Field Stands}

In 1973 when we first sampled the barbwire Russian thistle communities at Dodge Flat, Russian thistle still accounted for about $10 \%$ of the plants in the community (Table 1). By 1976, Russian thistle had disappeared from the community.

During this time the density of barbwire Russian thistle varied from 1.0 to 11.1 plants $/ \mathrm{m}^{2}$. Density of halogeton, the other alien annual species in the community, was low and remained relatively unaffected by the two Salsola species during the sampling period.

\section{Herbage Yield and Seed Production}

There was significant $(P=0.01)$ correlation between herbage yield and seed production for barbwire Russian thistle (Fig. 1). The maximum seed production was far below that reported for Russian thistle. Robbins et al. (1952) reported that Russian thistle seed production can reach 200,000 seeds/plant. In this study, seed production of barbwire Russian thistle seldom exceeded 1,000 seeds/plant and averaged 600 seeds/plant.

A significant correlation $(P=0.05)$ between values of density and seed production indicated a trend for barbwire Russian thistle to produce more seeds/plant when growing at higher density, but this relationship accounted for only $42 \%$ of the variation in seed production (Fig. 2). Barbwire Russian thistle seeds disperse beneath the canopy of the plant on which they are produced, whereas Russian thistle plants must tumble before the seeds are freed from the plant (Young and Evans 1979). This may account for the tendency of barbwire thistle plants to be clumped together, especially under the old plant canopies, which provide a favorable environment for germination. The tendency for seed production per plant to increase with increasing plant density indicates that the same environmental variables, particu-

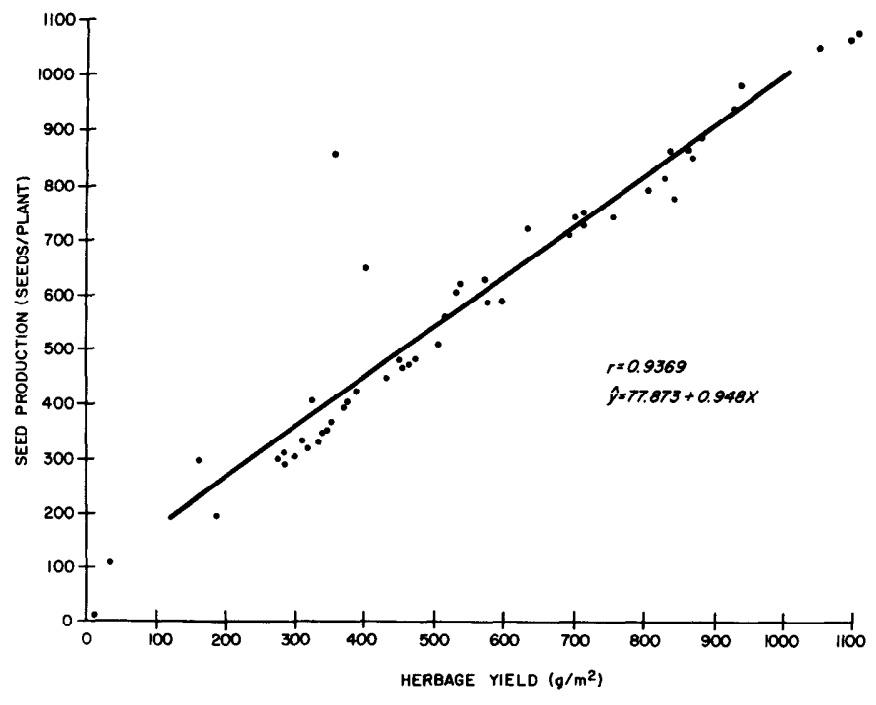

Fig. 1. Correlation coefficient (r) and partial regression equation for relationship between herbage yield $(\mathrm{x})$ and seed production $(\hat{\mathrm{y}})$ in barbwire Russian thistle.

larly rainfall, were affecting both parameters similarly and that densities were low enough that intraspecific competition was not a factor. However, the greater the plant density, the lighter the individual seed weight (Fig. 3). This finding suggests that at least toward the end of the growing season after flowering and when the seeds were maturing, intraspe-

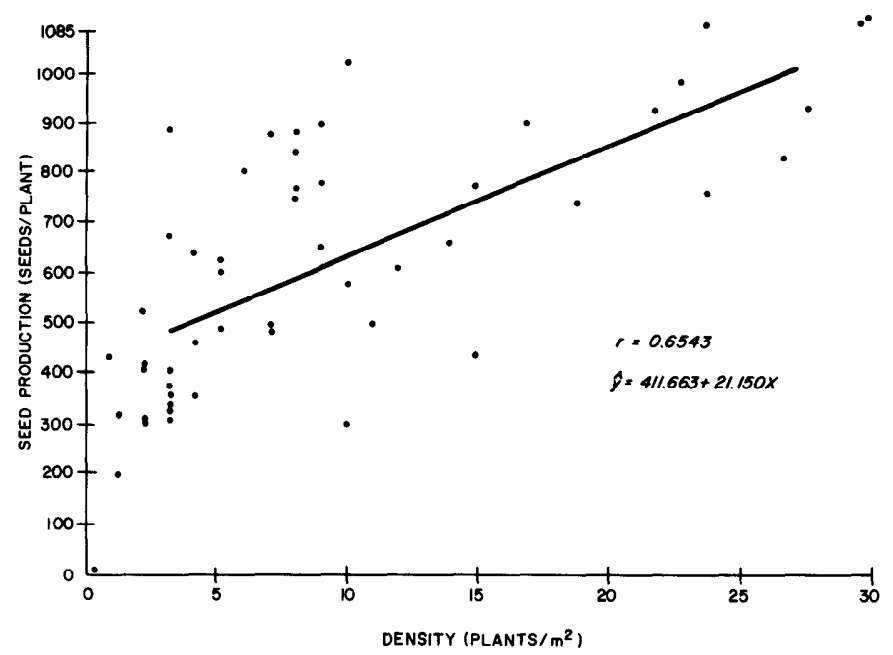

Fig. 2. Correlation coefficient (r) and partial regression equation for relationship between plant density $(\mathrm{x})$ and seed production $(\hat{\mathrm{y}})$ in barbwire Russian thistle.

Table 1. Species composition, as measured by frequency $(\%)$ and density (plants $\left./ \mathrm{m}^{2}\right)^{\mathrm{a}}$, of a degraded plant community in the Carson Desert of northwestern Nevada, 1973-1976.

\begin{tabular}{|c|c|c|c|c|c|c|c|c|}
\hline \multirow[b]{2}{*}{ Common Name } & \multicolumn{2}{|c|}{1973} & \multicolumn{2}{|c|}{1974} & \multicolumn{2}{|c|}{1975} & \multicolumn{2}{|c|}{1976} \\
\hline & Freq. & Density & Freq. & Density & Freq. & Density & Freq. & Density \\
\hline Barbwire Russian thistle & 79 & 1.0 & 86 & 7.2 & 89 & 1.3 & 98 & 11.1 \\
\hline Russian thistle & 11 & 0.1 & 6 & $\mathrm{~T}$ & 1 & $\mathrm{~T}$ & 0 & 0 \\
\hline Halogeton & 0 & $\mathrm{~T}$ & 5 & 1.3 & 0 & 0 & 1 & $\mathrm{~T}$ \\
\hline Indian ricegrass & 4 & 0 & 2 & $\mathrm{~T}$ & 8 & $T$ & 1 & $\mathrm{~T}$ \\
\hline Fourwing saltbush & 6 & $\mathrm{~T}$ & 0 & 0 & 1 & $\mathbf{T}$ & 0 & 0 \\
\hline Spiny hopsage & 0 & 0 & 1 & $\mathrm{~T}$ & 1 & $T$ & 0 & 0 \\
\hline
\end{tabular}

${ }^{\mathrm{a}} \mathrm{T}=$ trace $($ less than $0.1 \%)$. 


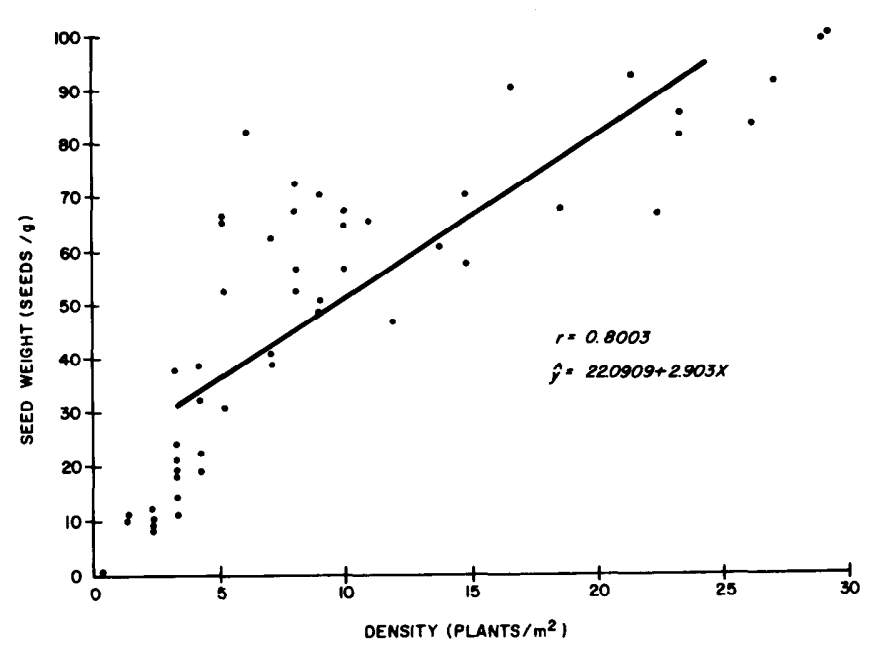

Fig. 3. Correlation coefficient $(\mathrm{r})$ and partial regression equation for relationship between plant density $(\mathrm{x})$ and seed weight $(\hat{\mathrm{y}})$ in barbwire Russian thistle.

cific competition for available moisture was affecting the plants.

These seed-production characteristics are probably some of the most important differences between barbwire Russian thistle and Russian thistle. Other than the reported maximums, seed-production data are not available for Russian thistle. The gross morphology of the two species of Salsola suggests greater seed production for Russian thistle plants; their size is extremely variable, but generally they are much larger than barbwire Russian thistle plants and the herbage is more finely divided, with a multitude of flowers.

\section{Seedbed Experiments \\ Agricultural Soil 1974-1975}

Planting 5,000 barbwire Russian thistle seeds $/ \mathrm{m}^{2}$ in December resulted in 25 seedlings per $\mathrm{m}^{2}$ the next May (Table 2). Planting in March resulted in double this density. In both December and March plantings of barbwire Russian thistle, some Russian thistle seedlings became established. The field where we planted was infested with Russian thistle, and the occasional seedling establishment apparently resulted from a Russian thistle plant tumbling across the plots. The accidental establishment of Russian thistle amounted to more than $20 \%$ of the March-seeding establishment of barbwire Russian thistle, the seeded species. In contrast, where Russian thistle was seeded alone, no barb- wire Russian thistle seedlings spontaneously established.

December planting of 5,000 Russian thistle seeds $/ \mathrm{m}^{2}$ resulted in establishment of only 13 seedlings $/ \mathrm{m}^{2}$ in May (Table 2). March planting resulted in establishment of 495 plants by May. This difference is a consequence of our use of year-old Russian thistle seeds whose afterripening requirements had been satisfied. Use of such seeds in the December planting resulted in winter germination and seedling mortality. We will consider this winter mortality in detail later.

When the two species of Salsola were grown together, the December planting resulted in only slight establishment of either species (Table 2). The March planting resulted in overwhelming dominance by Russian thistle.

\section{Agricultural Soil 1975-1976}

We repeated the basic establishment experiment at Reno in 1975 . This year we used only freshly harvested seeds that had temperature-related afterripening requirements. Essentially these afterripening requirements limit germination to a very restricted range of temperatures soon after maturity, and gradually become less restrictive during the winter (Young and Evans 1972a). We planted the seeds in December 1975 and by July 1976 an excellent stand of Russian thistle had been established (Table 3). In apparent response to a more favorable winter and spring environment the stand of barbwire Russian thistle established at Reno was much better than that in the previous year. However, the stand density was significantly $(\mathrm{P}=0.05)$ lower than that for Russian thistle alone or Russian thistle in combination with barbwire Russian thistle. Note that although the density of both Salsola species was numerically lower when they were planted together than when they were planted alone the differences were not significant $(P=0.05)$. The total number of seeds planted remained constant, so that only one half as many seeds of each species were available for germination when both species were planted together $\left(2,500 / \mathrm{m}^{2}\right)$ as in the single-species planting $\left(5,000 / \mathrm{m}^{2}\right)$. This indicates that the number of safesites for germination controlled total seedling establishment with Russian thistle establishing $79 \%$ and barbwire Russian thistle only $14 \%$ from seeds sown in combination. By comparison, when seeded alone Russian thistle established $45 \%$ and barbwire Russian thistle $15 \%$ from the seeds sown. Both in terms of utilization of and competition for available safesites, Russian thistle under semi-arid condition is better adapted than barbwire Russian thistle.

In this context, Harper's concept of "safesite" (Harper et al. 1961; Harper et al. 1965) refers to conditions of the soil surfaces that are suitable, in terms of available moisture and

Table 2. Density of barbwire Russian thistle and Russian thistle planted alone and in combination at 5,000 seeds $/ \mathrm{m}^{2}$ in $\mathrm{December} 1974$ and $\mathrm{March} 1975$ on an agricultural field at Reno, Nevada, and sampled in May 1975.

\begin{tabular}{|c|c|c|c|}
\hline \multirow[b]{2}{*}{ Common name of species planted ${ }^{\mathrm{a}}$} & \multirow[b]{2}{*}{ Month planted ${ }^{\mathrm{b}}$} & \multicolumn{2}{|c|}{ Density } \\
\hline & & Barbwire Russian thistle & Russian thistle \\
\hline & & (no. $/ \mathrm{m}^{2}$ ) & (no. $/ \mathrm{m}^{2}$ ) \\
\hline Barbwire Russian thistle & $\begin{array}{l}\text { December } \\
\text { March }\end{array}$ & $\begin{array}{l}25 \\
52\end{array}$ & $\begin{array}{l}2 \\
2\end{array}$ \\
\hline Russian thistle & $\begin{array}{l}\text { December } \\
\text { March }\end{array}$ & $\begin{array}{l}0 \\
0\end{array}$ & $\begin{array}{r}13 \\
495\end{array}$ \\
\hline $\begin{array}{l}\text { Barbwire Russian thistle } \\
\text { and Russian thistle }\end{array}$ & $\begin{array}{l}\text { December } \\
\text { March }\end{array}$ & $\begin{array}{l}13 \\
30\end{array}$ & $\begin{array}{r}6 \\
315\end{array}$ \\
\hline
\end{tabular}

${ }^{a}$ Seeds of Russian thistle were 1 year old and their afterripening requirements had been satisficd; all other sceds werc of the current year's production.

${ }^{\mathrm{b}}$ Seeds planted in December were raked into the surface $\mathrm{I} \mathrm{cm}$ of soil; seeds planted in March were sprinkled on the soil surface and left uncovered. 
Table 3. Density of barbwire Russian thistle, planted alone and in combination at 5,000 seeds/ $\mathrm{m}^{2}$ in December 1975 on a degraded plant community at Dodge Flat (in the northern Carson Desert) or on an agricultural soil at Reno, Nevada, and sampled in July 1976 . $^{\circ}$

\begin{tabular}{llcc}
\hline \hline & & \multicolumn{2}{c}{ Density } \\
\cline { 3 - 4 } Common name of species planted & Planting site & Barbwire Russian thistle & Russian thistle \\
\hline Barbwire Russian thistle & Carson Desert & 6 & 0 \\
Russian thistle & Reno & $740 \mathrm{~b}$ & $180 \mathrm{c}$ \\
& Carson Desert & 0 & 0 \\
Barbwire Russian thistle & Reno & $0 \mathrm{c}$ & $2300 \mathrm{a}$ \\
and Russian thistle & Carson Desert & 5 & 0 \\
\hline
\end{tabular}

a In the Reno experiment, means followed by the same letter are not significantly different at the 0.05 level of probablity as determined by Duncan's multiple range test.

favorable temperature, for the germination and establishment of the two species of Salsola as was described by Evans and Young (1972b) in reference to other annual rangeland species.

\section{Winter Mortality}

In 1974 when we planted year-old Russian thistle seeds that had their afterripening requirements satisfied, they germinated in midwinter (Fig. 4). The seedlings froze and were lost. In contrast, in 1975 when we planted freshly harvested seeds, the afterripening requirements delayed germination until spring, and the seedlings established.

The afterripening requirements for germination of seeds of barbwire Russian thistle are less stringent than those for Russian thistle (Young and Evans 1978). Germination of barbwire Russian thistle was gradually increasing during most of the winter and, in 1976 increased dramatically
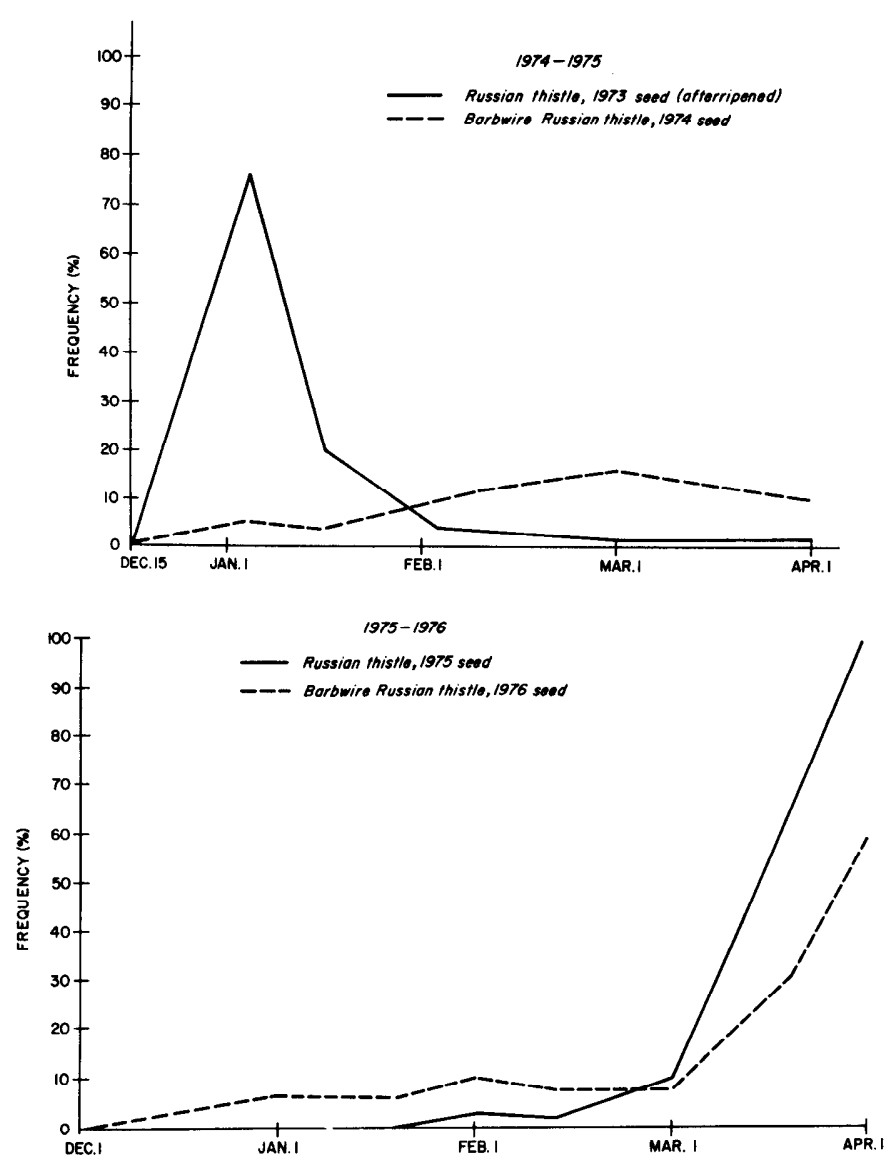

Fig. 4. Frequency of Russian thistle and barbwire Russian thistle seedlings during winter and spring of 1974-75 and 1975-76 at Reno, Nevada. around March 1, when Russian thistle first started to germinate. These observations indicate that barbwire Russian thistle seedlings are more winter hardy than Russian thistle seedlings and at least some barbwire Russian thistle can become established earlier than Russian thistle.

\section{Carson Desert 1975-1976}

We did not sample the Dodge Flat planting during the winter after seeding, but by the next July a very sparse stand of barbwire Russian thistle was established (Table 3). There was no establishment of Russian thistle, either spontaneous or resulting from the single-or mixed-species plantings.

The environmental potential of the seedbeds at Dodge Flat is markedly lower than at Reno. The average annual precipitation at Reno is $17.5 \mathrm{~cm}$; an estimate for Dodge Flat, based on the closest weather stations, is $10 \mathrm{~cm}$ or less. There was apparently sufficient environmental potential at Dodge Flat for some establishment of barbwire Russian thistle during the winter and early spring, when rainfall was relatively high. By the time the bulk of the Russian thistle seeds had their afterripening requirements satisfied, it was too late for germination and establishment because of the lack of rainfall in late spring.

In 1975 we sprinkled the Salsola seeds on the surface of the seedbed. Establishment of barbwire Russian thistle at Dodge Flat was about $0.1 \%$ of the seeds planted. The remainder of the seeds must have been lost through predation or failed to find safesites for germination. Evans and Young (1972b) showed the importance of surface topography and litter in providing the environmental potential necessary for germination of Russian thistle seeds. Germination of barbwire Russian thistle seeds on a bare seedbed is about $1 / 3$ of that with minimum soil or litter coverage (Young and Evans 1979). In natural situations, barbwire Russian thistle seeds are largely dispersed beneath the canopies of the plants that produce them (Young and Evans 1979); in contrast, Russian thistle seeds are largely dispersed by tumbling of the plants that produce them. Under the harsh conditions of an arid environment, mollification of temperature and moisture regimes by the litter accumulation of dead plants could be critical for success of germination and establishment (Evans and Young 1970).

The very low densities of barbwire Russian thistle that established at Dodge Flat may appear insignificant in comparison to the high densitics of Russian thistle (thousands of seedlings $/ \mathrm{m}^{2}$ ) that establish on agricultural soils. However, the seedling densities of barbwire Russian thistle in the seedbed experiment at Dodge Flat were not very different from the mature-plant densities we sampled in natural communities at this site (Table 1). So even with these low see- 
dling densities, enough plants were established to occupy the environmental potential.

In our seedbed studies we have considered only winterspring establishment. In the Great Basin, summer rains will also stimulate germination of Russian thistle seeds. During the course of this study, there was no rainfall adequate to start germination during the summer. After the study was completed in August 1976, 1 s $^{+} \mathrm{a}$ summer rains stimulated extensive germination in the Carson Desert. The resulting stands were sampled for another study and were composed exclusively of barbwire Russian thistle (unpublished data SEA-AR, Reno, Nev). The results of previous seed germination experiments (Young and Evans 1979) suggest that Russian thistle has an advantage over barbwire Russian thistle with respect to summer germination. However, after 4 years without summer rainfall, there may not have been any reserve of Russian thistle seeds in the soil. Studies of the longevity of Russian thistle seeds in agricultural soil indicate that $65 \%$ of the seeds germinate the 1 st year and few remain after 3 years (Chepil 1946).

In this study, we compared germination and establishment of two Salsola species under arid and semiarid conditions. This comparison is complex because it involves site specificity in terms of broad climatic zones; it involves germination safesites in terms of microenvironmental factors; and it involves interspecific competition for these germination safesites.

It would seem that specific adaptations of barbwire Russian thistle, in comparison to Russian thistle, permit it to become established in the Carson Desert and other arid areas of northern Nevada. These include: (1) earlier maturation and seed dispersal; (2) seed dispersal beneath the parent plants; and (3) less specific temperature afterripening requirements. Even with these apparent favorable adaptations establishment of barbwire Russian thistle was low.

Under semiarid conditions these adaptations are not particularly beneficial and Russian thistle with its large quanti- ties of seeds and high germinability out-establishes barbwire Russian thistle by far.

\section{Literature Cited}

Arnold, H.L. 1972. An analysis of the taxonomic status of a new taxon in the genus Salsola. Ph.D. Thesis, Utah State Univ., Logan, Utah.

Beatley, J.C. 1971. Ecological and geographical distribution of the vascular plants of southern Nye County and adjacent parts of Clark, Lincoln, and Esmeralda counties, Nevada. Univ. of California Press. Los Angeles, Calif. 49 p.

Beatley, J.C. 1973. Russian thistle (Salsda) species in western United States. J. Range Manage. 26: 225-226.

Billings, W.D. 1945. The plant associations of the Carson Desert region, western Nevada. Butler Univ. Bot. Stud. 7: 89-123.

Chepil, W.S. 1946. Germination of weed seeds. I. Longevity, periodicity of germination, and vitality of seeds in cultivated soil. Sci. Agr. 26:307-346.

Evans, R.A. and R.M. Love. 1957. The step-point of sampling-A practical tool in range research. J. Range Manage. 10:208-212.

Evans, R.A., and J.A. Young. 1970. Plant litter and establishment of alien annual weed species in rangeland communities. Weed Sci. 18: 697-703.

Evans, R.A. and J.A. Young. 1972a. Germination and establishment of Salsola in relation to seedbed environment. Part II. Seed distribution germination and seedling growth of Salsola and microenvironmental monitoring of the seedbed. Agron. J. 64: 219-224.

Evans, R.A., and J.A. Young. 1972b. Microsite requirements for establishment of annual rangeland weeds. Weed Sci. 20:350-356.

Harper, J.L., J.N. Chatsworthy, I.H. McNaughton, and G.R. Sagar. 1961. The evolution and ecology of closely related species living in the same area. Evolution 15: 209-227.

Harper, J.L., J.T. Williams, and G.R. Sagar. 1965. The behavior of seeds in soil. I. The heterogeneity of soil surfaces and its role in determining the establishment of plants from seed. J. Ecology 53:273-286.

Levy, E.B., and E.B. Madden. 1933. The point method of pasture analysis. N.Z. J. Agr. 46: 267-279.

Morrison, R.B. 1964. Lake Lahontan: Geology of the southern Carson desert Nevada, U.S. Geol. Serv. Prof. Paper No. 401.156 p.

Robbins, W.W., A.S. Crafts, and R.N. Raynor, 1952. Weed Control. McGraw-Hill Book Company, Inc., New York. 503 p.

Young, J.A., and R.A. Evans. 1972. Germination and establishement of Salsola in relation to seedbed environment. Part I. Temperature, afterripening, and moisture relations of Salsola as determined by laboratory studies. Agron. J. 64: 214-218.

Young, J.A., and R.A. Evans. 1979. Barbwire Russian thistle seed germination. J. Range Manage. (in press)

\title{
Special Management Needs of Alpine Ecosystems
}

\author{
edited by Douglas A. Johnson
}

This publication presents six papers given at a special symposium presented at the annual meeting of the Society for Range Management in Casper, Wyoming, in February, 1979. Titles include:

\author{
Alpine Ecosystems of Western North America \\ Physiological Responses of Plants in Tundra Grazing Systems \\ Range Management in the Alpine Zone \\ Hydrologic Aspects Related to the Management of Alpine Areas \\ Revegetation of Disturbed Alpine Rangelands \\ Future Management and Research Needs in Alpine Ecosystems
}

Extensive bibliographical material extends the value of the papers, which present current information about the mysterious world of the alpine tundra. Increased demands for food and fuel have created greater pressure on these fragile lands, and so current information about them would be of value to those responsible for their use and reclamation, environmentalists, research students, and individuals interested in an unusual and fascinating ecosystem. Soft-bound $\bullet 120$ pages $\bullet \$ 4.50$ postpaid. 